\title{
LANDSCHAPPELIJKE AUTHENTICITEIT
}

HET LANDSCHAP ALS LEVEND SYSTEEM,

GESCHIEDENIS EN

RUIMTELIJKE BELEVING

STEFFEN NIJHUIS

Echtheid, originaliteit en authenticiteit zijn termen die qua betekenis dicht

bij elkaar liggen en vaak in verband worden gebracht met gebruik, -

behoud en waardering van cultureel erfgoed zoals schilderijen,

sculpturen en gebouwen. Maar hoe zit dat bij landschap?

Bestaat er zoiets als landschappelijke authenticiteit?

En hoe kan je dié begrijpen? -

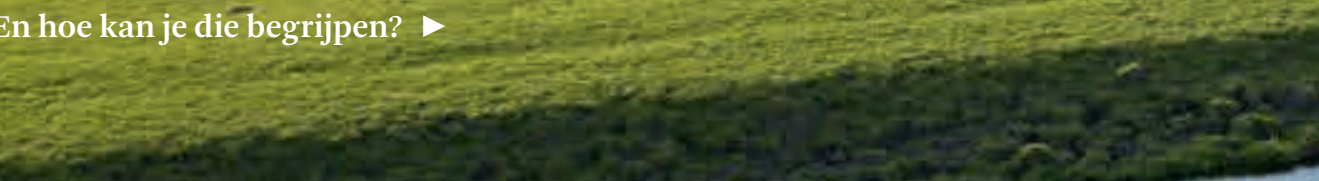

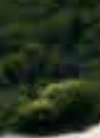

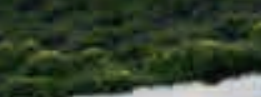

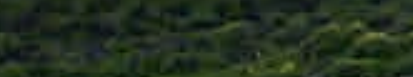
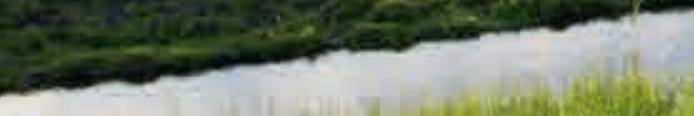

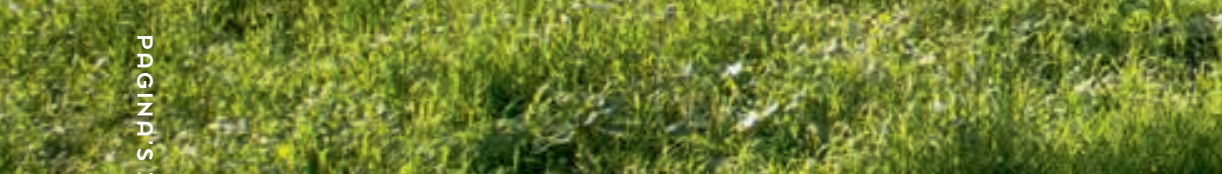

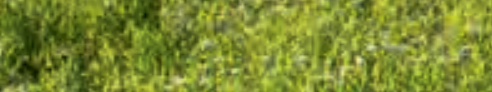

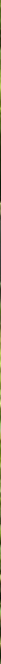

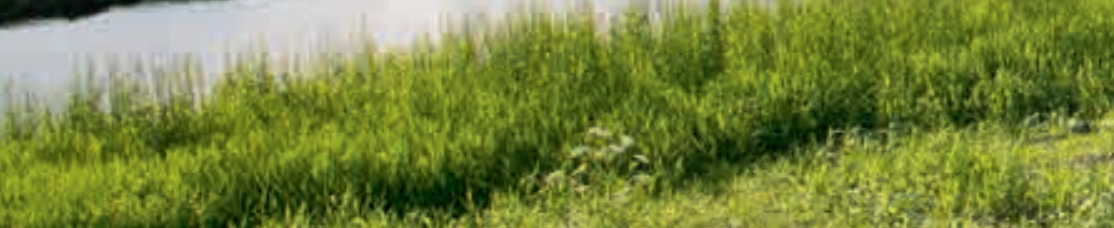

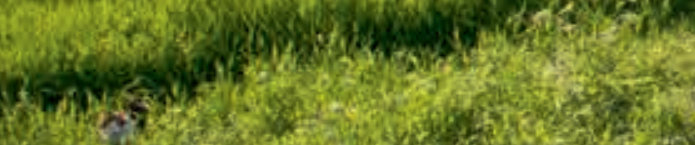


1. Droogmakerijen zijn als landschap vaak duidelijk herkenbaar. De Beemster is een bekend voorbeeld met zijn kenmerkende grillige ringdijk, orthogonale beplantings- en verkavelingspatroon en stolpboerderijen ver beneden de zeespiegel (foto Hans Lemmens, Algemeen Nederlands Persbureau)

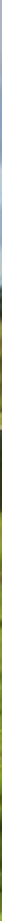

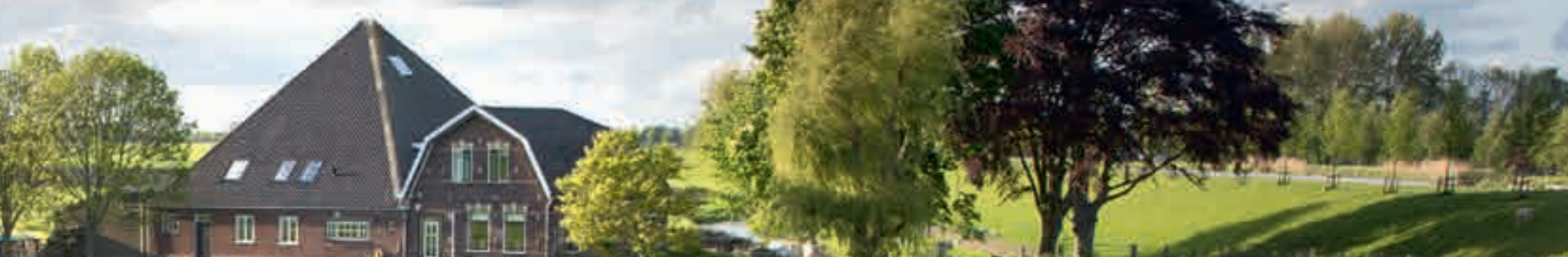

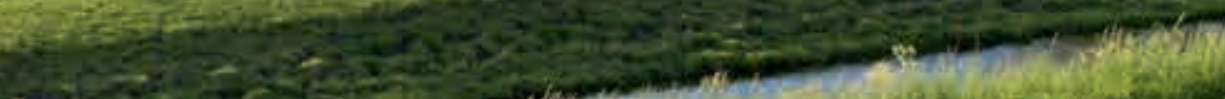
sto

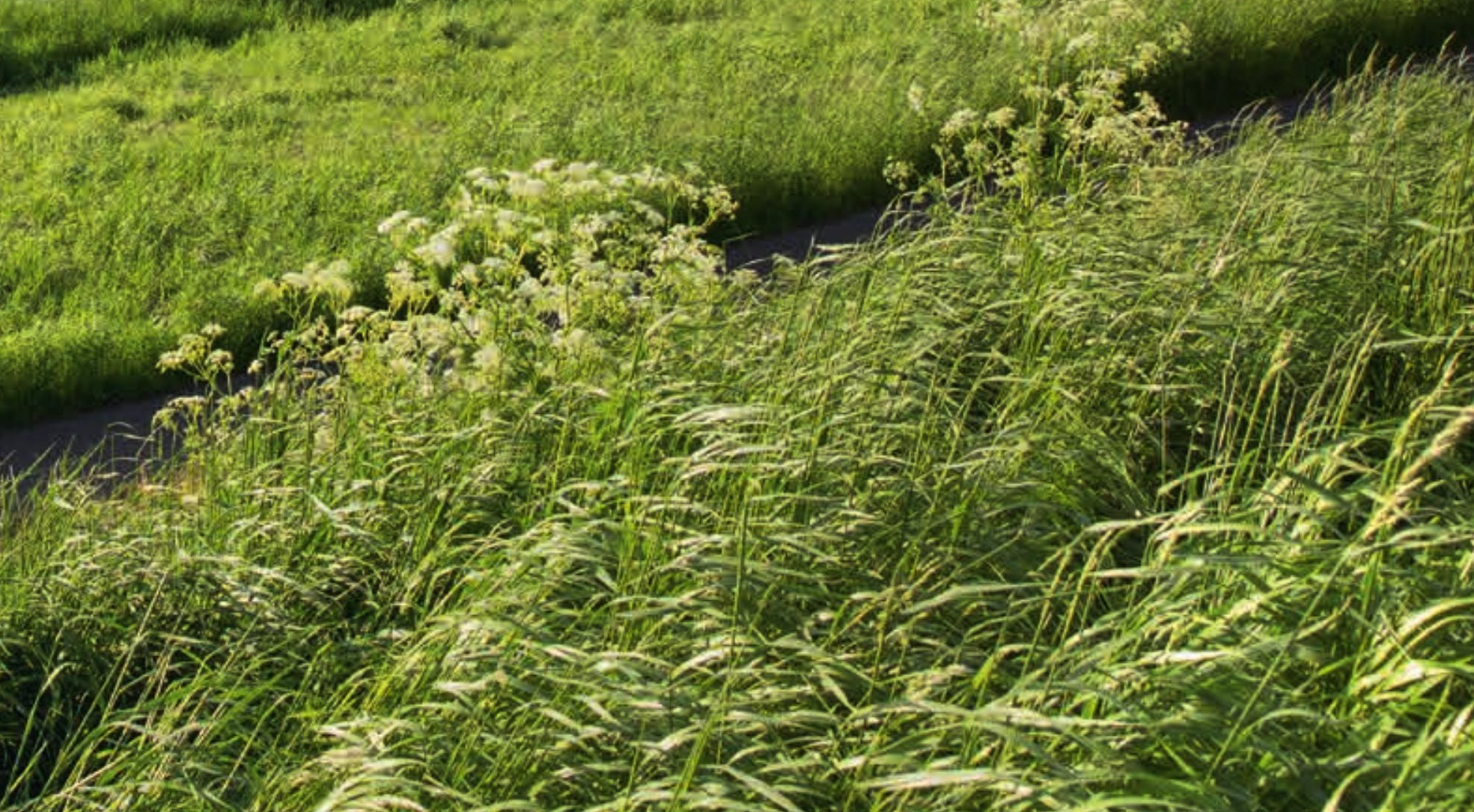


Met authenticiteit wordt hier bedoeld dat het landschap zijn eigen kenmerken draagt en zich onderscheidt door zijn eigen karakter. Met andere woorden: landschappelijke authenticiteit heeft te maken met ruimtelijke kwaliteit en identiteit. Hierbij speelt oriëntatie in tijd en ruimte een rol, maar ook schoonheid, (multi)functionaliteit, ecologische variatie en samenhang. De verscheidenheid aan verbanden en interacties tussen deze aspecten maakt landschappelijke authenticiteit een complexe zaak. In deze bijdrage wordt betoogd dat wij landschappelijke authenticiteit kunnen begrijpen door het landschap in samenhang te bekijken: als levend systeem, geschiedenis en ruimtelijke beleving.

\section{LANDSCHAP ALS LEVEND SYSTEEM}

Een veelgebruikte definitie van landschap is: 'een gebied, zoals waargenomen door mensen, waarvan het karakter het resultaat is van de actie en interactie van natuurlijke en/of menselijke factoren'. ${ }^{1}$ Deze definitie benadrukt het dynamische karakter van landschap. Landschap verandert, met en zonder menselijke invloed. Soms vinden er ingrijpende veranderingen plaats, soms minder ingrijpende. Soms duurt het lang voordat wijzigingen zichtbaar worden, zoals bij gevolgen van klimaatverandering. Maar het kan ook snel gaan, bijvoorbeeld wanneer in agrarisch gebied een nieuwbouwwijk wordt gerealiseerd. Daarom is het landschap op te vatten als een levend systeem, dat wil zeggen een complex en dynamisch stelsel van deelsystemen dat voortdurend verandert onder invloed van natuurlijke processen, maatschappelijke eisen en technische mogelijkheden. Het landschap is daarmee een interface tussen natuur en maatschappij die zich manifesteert in een materiële ruimte die zowel uit structuren als uit processen bestaat.

Om de samenhang en heterogeniteit van landschap in ruimte en tijd te begrijpen, is het belangrijk om de chorologische (horizontale) en topologische (verticale) relaties te bestuderen. ${ }^{2}$ Een praktische en gangbare methode hiervoor is het ontleden van het landschap in lagen en het ordenen ervan naar het niveau van invloed en dynamiek van verandering. ${ }^{3}$

\section{LANDSCHAP IN LAGEN}

Het in lagen uiteenleggen van het landschap is een manier om grip te krijgen op de verschillende (deel) systemen en hun relaties. Deze ontleding in lagen moet niet worden gezien als een statische of hiërarchische ordening. In plaats daarvan gaat het om afzonderlijke lagen die elkaar in meer of mindere mate beïnvloeden, en waarvan de invloed ook nog eens door de tijd heen kan veranderen. Er zijn veel typen lagenbenaderingen in omloop, zoals het triplexmodel waarin onderscheid wordt gemaakt tussen de abiotische (reliëf, water, bodem), biotische (flora en fauna) en antropo- gene (menselijk ingrijpen) laag. ${ }^{4}$ Een ander bekend lagenmodel ontleedt het landschap in substraat, netwerken en verstedelijking. ${ }^{5}$ Hoewel nuttig in hun toepassing, worden sociale en culturele aspecten daarbij niet expliciet geadresseerd. Alternatieve lagenbenaderingen benadrukken dat het begrip van de relatie tussen de fysieke omgeving (hardware), menselijk handelen (software) en culturele, institutionele en conceptuele opvattingen (orgware) essentieel is om het landschap en zijn wording te begrijpen. ${ }^{6}$ Gebaseerd op het voorgaande worden de volgende drie lagen onderscheiden om het landschap te begrijpen als een dynamische interactie tussen mens en natuur.

\section{DE NATUURLIJKE CONTEXT (LAAG 1)}

De natuurlijke context wordt gevormd door reliëf, water, bodem, geologische ondergrond en klimaat en de daarmee samenhangende ecosystemen. Deze laag moet worden gezien als een exogene, fysieke factor, met specifieke kenmerken die ook aan verandering onderhevig zijn. Denk aan geologische en geomorfologische processen zoals tektoniek van aardplaten, erosie en sedimentatie door wind en water (afb. 2). Natuurlijke successie waarbij bijvoorbeeld open grasland verandert in een bos of halfopen parklandschap bij natuurlijke begrazing is hiervan een concreet voorbeeld. De natuurlijke context moet niet worden beschouwd als een op zichzelf staand gegeven, maar als een centrale en onlosmakelijke component van het systeem die voor een groot deel bepaalt wat de gebruiksmogelijkheden zijn. De dynamiek van deze basisconditie wordt gekenmerkt door een langzaam, vaak bijna onmerkbaar, proces van verandering, herhaling en natuurlijke cycli.

\section{MENSELIJKE MODIFICATIES EN INTERVENTIES (LAAG 2)}

Menselijk ingrijpen is onlosmakelijk verbonden met het in gebruik nemen van de natuurlijke context voor wonen, werken en recreatie. De mens eigent zich de natuurlijke omgeving toe door ingrepen zoals de aanleg van wegen, landaanwinning, bedijking en kanalisering van waterlopen, de bouw van dorpen en steden, drainage en irrigatie die zichtbaar worden in onder meer verschillende verkavelingspatronen en waterinfrastructuur. Dat toe-eigeningsproces heeft door de geschiedenis heen geleid tot vele opeenvolgende, soms drastische veranderingen van het landschap. De dynamiek van deze laag is gerelateerd aan de lange termijn van de sociale, economische en culturele geschiedenis.

CULTUUR, ORGANISATIE EN POLITIEK (LAAG 3)

Deze laag omvat de culturele, spirituele, en religieuze opvattingen over de natuurlijke context en de omgang daarmee, waaronder de stand van wetenschap en techniek, organisatievormen, politieke stromingen, vorm- 


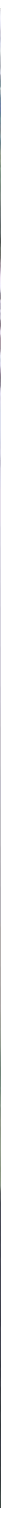

2. Het dynamische karakter van landschap is goed zichtbaar langs de Nederlandse kust, waar processen van erosie en sedimentatie het land continu aanpassen (foto Joop van Houdt, Rijkswaterstaat)

gevingsconcepten en schoonheidsidealen. Zo heeft water in verschillende culturen verschillende betekenissen, wat tot uiting kan komen in landschapsarchitectonische bewerkingen in tuinen en parken. Mede door geopolitieke en economische overwegingen werden de veengebieden van West-Nederland ontgonnen. Een ander voorbeeld is landaanwinning voor voedselproductie, wonen, recreatie en natuurontwikkeling in het IJsselmeergebied. De dynamiek van deze laag is gerelateerd aan de relatief korte termijn, gekoppeld aan mensen en politiek.

Het begrijpen van landschappelijke authenticiteit is inherent aan het begrip van de lagen en hun relaties die het landschappelijke systeem vormen. Het landschap is daarbij een relationele structuur die schalen en ruimtelijke, ecologische, functionele en sociale entiteiten met elkaar verbindt en beïnvloedt. Het land- schap is dus niet alleen een holistisch systeem, maar ook een schaalcontinuüm dat wij alleen kunnen begrijpen door naar verschillende ruimtelijke schalen en hun relaties te kijken.

\section{LANDSCHAP ALS GESCHIEDENIS}

Tijd is een belangrijke factor voor landschappelijke authenticiteit. In de loop van de tijd ondergaat het landschap transformaties waarbij selecties worden gemaakt op basis van mogelijkheden en waardebepaling. Sommige structuren, patronen en vormen blijven behouden, andere ontwikkelen zich of worden vervangen door nieuwe. Door die transformatie of reeks van transformaties ontstaat meestal een evenwicht tussen landschappelijke structuren die meer permanent zijn en andere die juist sneller veranderen. ${ }^{7}$ De meer permanente zijn vaak moeilijker te veranderen 
schappelijke gelaagdheid en de leesbaarheid verloren kunnen gaan en het risico bestaat dat de culturele identiteit verdwijnt. Om dit te voorkomen is een aanpak noodzakelijk die wordt gekenmerkt door 'beheer van verandering', met als doel een toekomstig landschap te creëren waarin het verleden in de een of andere vorm een passende rol speelt. ${ }^{16}$ Hierbij hoort een dynamisch en politiek proces dat zich niet beperkt tot het domein van de landschapsexperts, maar waarbij ook lokale belanghebbenden actief betrokken zijn. ${ }^{17}$ Op deze manier kan dan het publieke debat over de betekenis van (historische) landschapskarakteristieken en het gebruik ervan leiden tot zorgvuldige afwegingen over landschappelijke authenticiteit.

\section{NOTEN}

1 Council of Europe, European Landscape Convention, Florence, 3; zie ook: I. Zonneveld, Land Ecology. An Introduction to Landscape Ecology as a Base for Land Evaluation, Land Management and Conservation, Amsterdam 1995.

2 Zonneveld 1995 (noot 1). In NoordwestEuropa zijn er lange tradities van landschapskarakterisering en fysisch-geografisch en historisch-geografisch onderzoek die zich richten op dergelijke relaties. Elk van deze onderzoeksvelden heeft zijn eigen onderzoeksperspectief en instrumentarium. Zie voor een overzicht bijvoorbeeld: M. Antrop en V. van Eetvelde, Landscape Perspectives. The Holistic Nature of Landscape, Bazel 2019. 3 F. Braudel, La Méditerranee. La part du milieu, Parijs 1966; S. Nijhuis en M. Pouderoijen, 'Mapping Urbanized Deltas', in: H. Meyer en S. Nijhuis (red.), Urbanized Deltas in Transition, Amsterdam 2014, 10-22.

4 P. Vrijlandt en K. Kerkstra, Mergelland. Landschap en mergelwinning, Wageningen 1976.

5 M. de Hoog, D. Sijmons en S. Verschuu- ren, 'Herontwerp van het laagland', in: D. Frieling (red.), Het metropolitane debat, Bussum 1998.

6 Braudel 1966 (noot 3); G. Dobrov, 'The Strategy for Organized Technology in the Light of Hard-, Soft-, and Org-ware Interaction', Long Range Planning 12 (1979) 4, 79-9o; T. Tvedt en T. Oestigaard, 'Urban Water Systems. A Conceptual Framework', in: T. Tvedt (red.), A History of Water. Series III, Volume 1. Water and Urbanization, Londen 2014, 1-21.

7 M. Bobic, The Role of Time Function in City, Spatial Structures and Present, Aldershot 1990.

8 N. Roymans e.a., 'Landscape Biography as Research Strategy. The Case of the South Netherlands Project', Landscape Research 34 (2009) 3, 337-359.

9 Voor landschap als biografie, zie M. Samuels, 'The Biography of Landscape', in: D. Meinig (red.), The Interpretation of Landscape, New York 1979, 51-88. Voor landschap als palimpsest, zie A. Corboz, 'The Land as Palimpsest', Diogenes 31 (1983) 121, 21-34.

10 C. Sauer, 'The Morphology of Landscape', University of California Publicati- ons in Geography 2 (1925) 2, 19-54; D. Whittlesey, 'Sequent Occupance', Annals of the Association of American Geographers 19 (1929) 3, 162-165.

11 W. van Toorn, Leesbaar landschap, Amsterdam 1998, 65.

12 J. J. Gibson, The Ecological Approach to Visual Perception, Hillsdale 1986.

13 J.G. Granö, 'Reine Geographie. Eine methodologische Studie beleuchtet mit Beispielen aus Finnland und Estland', Acta Geographica 2 (1929) 2, 202.

14 J.F. Coeterier, Hoe beleven wij onze omgeving?, Wijchen 2000.

15 M. Antrop, 'Why Landscapes of the Past Are Important for the Future', Landscape and Urban Planning 70 (2005), 21-34.

16 G. Fairclough, 'New Heritage, an Introductory Essay. People, Landscape and Change', in: G. Fairclough (red.), The Heritage Reader, Londen 2008, 297-312.

17 H. Renes, 'Different Methods for the Protection of Cultural Landscapes', in: H. Palang e.a. (red.), European Rural Landscapes. Persistence and Change in a Globalising Environment, Dordrecht 2004, 333-344.

DR. ING. S. NIJHUIS is hoofd van het landschapsarchitectuur-onderzoeksprogramma en universitair hoofddocent landschapsarchitectuur bij de Technische Universiteit Delft, faculteit Bouwkunde, afdeling Urbanism. De kern van zijn werk bestaat uit onderzoek naar landschappelijke benaderingen voor regionale ontwikkeling, GIStoepassingen in landschapsonderzoek, ontwerp- en onderzoeksmethoden in landschapsarchitectuur, en polderlandschappen. www.steffennijhuis.nl

\section{LANDSCAPE AUTHENTICITY}

\section{THE LANDSCAPE AS A LIVING SYSTEM, HISTORY AND SPATIAL EXPERIENCE}

\section{STEFFEN NIJHUIS}

Landscape authenticity relates to spatial quality and identity. Orientation in time and space are relevant, as are beauty, (multi)functionality, ecological variation and coherence. Owing to the diversity of connections and interactions between these aspects, landscape authenticity is a complex matter. This article contends that landscape authenticity can be understood by looking at the landscape as an integrated whole: as a living system, as history and as spatial experience. The landscape changes even without human intervention. The legibility of the landscape is crucial to how it is perceived and valued. The role of time is obvious and is characterized by a selective and incremental process whereby some structures endure and are adapted, while others make way for new structures. Landscape authenticity is not about fossilizing the landscape: a landscape cannot be preserved unchanged given that it is itself the outcome of continuous transformation. Understanding the evolution of the landscape is therefore just as important as the visible result. 